PEDAGÓGUSKÉPZÉS, 10-11 (39-40), 2012-2013. 211-215.

\title{
MEGHATÁROZÓ FEJEZETEK AZ EGYKORI BUDAI TANÍTÓKÉPZŐ ÉS ÉPÜLETE 20. SZÁZADI TÖRTÉNETÉBÖL
}

\author{
GOMBOS NORBERT \\ a Szent István Egyetem Gazdaság- és Társadalomtudományi Karának \\ egyetemi docense \\ Gombos.Norbert@gtk.szie.hu
}

Az Eötvös József által a kiegyezést követően létrehozott állami tanítóképzés meghatározó szerepet játszott a hazai kisgyermeknevelés történetében. Az 1948-as államosításig kisebbségben lévő állami tanítóképezdék vezetőinek, tanárainak alapvető törekvése volt a tanítóképzés megújítása, állandó fejlesztése, az új eredmények integrálása a képzés rendszerébe. Nem véletlenül tartották e képezdéket a tanítóképzési mozgalom ,zászlóshajóinak”. Különösen igaz ez az állítás az egykori budai képzőre, mely 1869-es alapításával az első volt a maga nemében, és már a dualizmus időszakában is a képzési rendszer fejlesztésének élvonalában járt (gondoljunk csak a Gyertyánffy István vezetésével 1873-ban létrejött Peadagogiumra). Az egykori budai képző a 20. század elején - 1911-ben - foglalta el azt az épületet, amelyben jogutódja ma is elhelyezést nyer. A centenárium alkalmából a jogutód ELTE Tanítóés Óvóképző Kar Tudományos Bizottsága 2011 áprilisában konferenciát rendezett „Tanitó- és óvodapedagógus-képzés a középfoktól az egyetemi oktatásig” címmel, melyen felidézték az egykori budai képző - forradalmakon és ellenforradalmakon, világháborúkon és rendszerváltásokon, államosításokon és átszervezéseken átívelő elmúlt száz évének néhány meghatározó fejezetét. A konferencia előadói nem pusztán szakterületük elismert, tekintélyes müvelöi, kutatói, de az egykori történések aktív résztvevői, szereplői, sőt alakítói is, akik személyes visszaemlékezéseikkel, az akkori szerepük - nem egy esetben kritikus - elemzésével kívánták bemutatni azt a küzdelmet, amelyet a tanítóképzés e budai fellegvárában - elsősorban az elmúlt 25-30 évben - folytattak, a tanítóképzés önállóságának, autonómiájának megőrzéséért, a képzés színvonalának emeléséért. A konferencia előadásainak tanulmányokká bővített, szerkesztett, illetve jelentős forrásbázissal kiegészített változata jelent meg abban a tanulmánykötetben, melyet Donáth Péter, az Eötvös Loránd Tudományegyetem Tanitó- és Óvóképzö Kar tanszékvezetö egyetemi tanára szerkesztett, és amely 2012-ben a Trezor Kiadó jóvoltából került napvilágra. A kötet - a szerkesztő által megfogalmazott - fontos vállalása, hogy a konferencián részt vett szükebb körön kívül a téma iránt érdeklődő neveléstudósok, neveléstörténészek, pedagógusok, tanítók, egykori és mai tanárok, öregdiákok és jelenlegi hallga- 
tók, valamint a kerületi lokálpatrióták is megismerhessék az egykori budai képző és épülete elmúlt száz évének néhány meghatározó történését.

A kötetben szereplö tanulmányokat az alábbi három nagy témakör köré fókuszálta a szerkesztő:

I. „A budai kisérleti négyéves képzéstöl az országos tantervfejlesztésig”

II. „Szervezeti, tartalmi kihívások és válaszok”

III. „Ha e százéves falak beszélni tudnának...”

Az első nagy egységben képet kaphatunk arról a komplex folyamatról, amely a Budapesti Tanítóképző Főiskolán, az 1980-as évek közepén, a négy évfolyamos kísérleti képzés koncepciójának kialakításával indult, és amely e képzési forma elfogadtatásán, bevezetésén át, annak a bolognai rendszerü felsőoktatási struktúrába történő beillesztéséig vezetett. Hunyady Györgyné, az ELTE Tanitó- és Óvóképzö Kar Neveléstudományi Tanszékének föiskolai tanára a „Rendszerváltás a tanitóképzésben. Kisérleti négyéves képzés a budai tanitóképzőben (1986-1994)” címü tanulmányában felvázolja azt a komplex folyamatot, amely a Budapesti Tanítóképző Főiskola életét, szakmai és tudományos munkáját a rendszerváltás körüli években meghatározta. A szerző - aki 1984 és 1992 között a budai tanítóképző főigazgatói posztját töltötte be - bő forrásanyagra támaszkodva mutatja be a kísérleti négy évfolyamos tanítóképzési koncepció kialakulásának folyamatát, az új struktúra megalapozásához szükséges fejlesztő kutatás sajátosságait és eredményeit, az új képzési szisztéma elfogadtatását és országossá válását, illetve annak „utóéletét” (vagyis integrálódását a bolognai folyamat komplex rendszerébe). Hunyady Györgyné széles bázisra - köztük saját korabeli emlékeire, élményeire, benyomásaira is - alapozva elemzi és értékeli a „tanitóképzés rendszerváltásaként” aposztrofált folyamatot, mely - mind szervezeti, mind tartalmi, illetve szakmai tekintetben - döntő mértékben meghatározta a Budapesti Tanítóképző Főiskola (mint az új képzési rendszer kimunkálásában és bevezetésében úttörő intézmény), valamint a társintézmények, föiskolák életét és oktatómunkáját a rendszerváltás körüli, illetve az azt követő másfél évtizedben. Podráczky Judit, az ELTE Tanitó- és Óvóképzö Kar Neveléstudományi Tanszékének tanszékvezetö föiskolai docense „A budai képzö, mint a tanitó- és óvóképzés országos szakmai egyeztetö fórumának központja. (A Tantervfejlesztö Bizottság tevékenysége)" címü tanulmányában annak az országos szakmai fórumnak az elmúlt közel negyedszázados müködését, tevékenységét és eredményeit tekinti át (széleskörü forrásanyagra támaszkodva), mely a tanítóképzéssel összefüggő szervezeti és tartalmi kérdések egyezetése céljából jött létre. A Tantervfejlesztő Bizottság 1987-ben alakult meg, és ugyan az elmúlt majd 25 évben néhány alkalommal nevet módosított (1994: Országos Tantervfejlesztő Bizottság), illetve változtatott (2004: Országos Programfejlesztő Bizottság), tevékenységének, feladatának lényege változatlan maradt: a tanító- és óvóképzés (külön szakmai csoportot alkottak az óvóképzés képviselői a Bizottságon belül) elött álló aktuális szakmai kihívások áttekintése, valamint 
az azzal összefüggő feladatok kijelölése. A szerző - aki 2008 óta a Bizottság vezetője is egyben - az alábbi három fö terület köré fókuszálja a bizottsági munka bemutatását és elemzését: (1) a négy évfolyamos kísérleti képzés előkészítése és bevezetése (1987-1990), (2) a négy évfolyamos tanítóképzés képesítési követelményeinek kidolgozása, illetve a képzés eredményességének vizsgálata (1990-2002), valamint (3) a bolognai rendszerben folyó tanítóképzés képzési és kimeneti követelményeinek kidolgozása (2004-2005), és a bolognai rendszerben folyó tanítóképzés beválásának vizsgálata (2009-től). Podráczky Judit mindvégig kiemeli annak a jelentőségét, hogy ennek a fontos szakmai mühelynek a budai képző épülete adott otthont, sőt vezetőjét is mindig ez az intézmény delegálta, bizonyítva ezzel azt, hogy a budai képezde egészen napjainkig megőrizte egykori „zászlóshajó” szerepét, szellemi központ funkcióját.

A kötet második nagy egységében - elsősorban az ezredfordulót megelöző, illetve az azt követő idöszakra vonatkoztatva - a tanítóképzést érintő szervezeti és tartami kihívások, valamint a budai képző arra adott válaszainak elemzése kerül terítékre. Kelemen Elemér, az ELTE Tanitó- és Óvóképzö Kar Neveléstudományi Tanszékének professor emeritusa „A Budapesti Tanitóképzö Főiskolától az ELTE Tanitó- és Óvóképzö Főiskolai Karáig" címü rendkívül izgalmas tanulmányában felvázolja azt a küzdelmes folyamatot, amelyet az intézmény vezetése és munkatársi gárdája folytatott az egykori budai képző szervezeti önállóságának megörzéséért, a felsőoktatási integráció felgyorsult folyamatában. A szerző - aki a kérdéses időszakban az intézmény főigazgatója volt - alapos forrásbázisra építve tárja fel azt a nehéz időszakot, amelyben a budai képző oktatói és vezetői igyekeztek meg-, és kiismerni az oktatáspolitika - gyakorta hektikus - döntési folyamatait, illetve megtenni az adott pillanatban leginkább helyesnek és szükségesnek tartott lépéseket. Kelemen Elemér több helyütt is rámutat arra - többek között saját visszaemlékezései alapján -, hogy az egyébként is túlterhelt oktatói gárda számára milyen további komoly kihívást jelentett ez az időszak, mely így óhatatlanul rányomta a bélyegét a szakmai munka színvonalára is. A tanulmány - melynek mellékletében korabeli dokumentumokat is tanulmányozhatunk - kiváló képet fest arról, miként küzd/küzdhet egy szakmai kollektíva az oktatáspolitika sokszor értelmetlen és kiismerhetetlen döntéshozatali mechanizmusaival. A szerző munkája e tekintetben messze túlmutat a vizsgált korszakra vonatkoztatható tanulságokon.

Mikonya György, az ELTE Tanitó- és Óvóképzö Kar dékánja a „Kihivások és válaszok a kora gyermekkori nevelés területén az ELTE Tanitó- és Óvóképzö Karán" címü tanulmányában kísérletet tesz arra, hogy felvázolja milyen feladatok állnak az ezredforduló után, a felsőoktatási integráció, valamint a bolognai képzési rendszerben a tanító- és óvóképzés (új megközelítésben: a kora gyermekkori nevelés) előtt. A szerző nemzetközi, oktatáspolitikai, illetve történeti összefüggésekbe ágyazva elemzi a tanító- és óvóképzés múltját, helyzetét, lehetséges fejlődési perspektíváit, különös tekintettel a budai képzöben folyó szakmai és tudományos mun- 
kára. A vázolt helyzetképre alapozva Mikonya György bemutatja azokat a javaslatokat, melyek a Kisgyermek-nevelési Módszertani Központ és Laboratórium létrehozására és tevékenységére irányulnak. A szerző a Módszertani Központ szerepét elsősorban az intézményi szakmai és tudományos mühelymunka szervezésében, irányításában látja. A tanulmány egyértelmủen bizonyítja, hogy a budai képző megfelelő alapokkal és feltételekkel rendelkezik az egyre inkább önállósuló tudományos terület - a kora gyermekkori nevelés - magas színvonalú müveléséhez, gondozásához (mely egyébként az ELTE Pedagógiai és Pszichológiai Kar Neveléstudományi Doktori Iskolájával való együttmüködésben eredményesen realizálódik is, hozzájárulva a tanítói hivatás zsákutcás jellege maradványainak végleges felszámolásához).

A kötet harmadik nagy fejezete minden tekintetben (témájában, felépítésében, tartalmában és terjedelmében) erőteljesen eltér az első kettőtől, hiszen egy olyan történelmi esemény elözményeiről, lefolyásáról és - legföképpen - következményeiről ad hiteles képet, mely a budai képző most százéves épületében 1919-ben történt. Donáth Péter, az ELTE Tanitó- és Óvóképzö Kar Társadalomtudományi Tanszékének tanszékvezetö egyetemi tanára, az MTA doktora „A Cserny-különitmény rémtettei »Mozdony utcai laktanyájukban « 1919 júliusában” című tanulmányában komoly forrásmunkára támaszkodva mutatja be a Cserny József vezette csoport által a Tanácsköztársaság idején a budai képző Mozdony utcai épületének pincéjében elkövetett politikai gyilkosságok hátterét és következményeit. A történet aktualitását egy - a közelmúltban a budai képző épületének falán - felavatott emléktábla jelenti, mely az 1919-ben meggyilkolt csendőrtiszteknek állít emléket. Donáth Péter igen alapos levéltári kutatómunkára alapozva feltárja a budai képző épületében 1919 júliusában történteket, annak előzményeit és következményeit. A tanulmány több vonatkozásban is megvilágítja a Cserny József vezette különítmény tetteit és annak következményeit. A szerző bemutatja a kortársak vélekedéseit (pro és kontra), elemzi a későbbi vádiratban szereplő tényállásokat, illetve a csoport tagjainak védekezését, rávilágít a bírósági tárgyalás sajtóbeli interpretációira, áttekinti a csoportnak a Tanácsköztársaság vezetőihez füződő viszonyát. Végül, számba veszi a megtorló ítéletek kapcsán felvetődő kérdéseket, illetve kétségeket, valamint feltárja a budai képző akkori igazgatójának - Quint Józsefnek - az épületben történtekkel kapcsolatos jelentéseit, az okozott károk mértékét.

Donáth Péter munkája kiváló képet fest az egymásnak feszülő politikai oldalak küzdelméröl, harcairól, melyek az egyébként is katasztrofális helyzetben (a háború elvesztése, a Monarchia szétesése) lévő ország problémáit tovább mélyítették. A tanulmány végén megismerhetjük a budai képző épületében megölt csendőrtisztek emlékezetének megőrzése céljából a tanítóképzőben foganatosított lépéseket, melyek az idő múlásával egyre inkább beleolvadtak a hősök napi megemlékezésekbe. Donáth Péter tanulmányának egyik legfőbb értéke, hogy a konkrét történések bemu- 
tatásán, elemzésén és értékelésén túllépve rámutat egy olyan rendszer genezisére, mely már születésekor magában hordozta annak az ideológiának a magvát, amely negyedszázad múltán, az ország második világháborús pusztulásához vezetett.

A , Sorsforditó mozzanatok...” tanulmánykötet méltó emléket állít az egykori budai képző centenáriumát ünneplő épületének, az Eötvös alapította állami tanítóképzésnek. Tanulmányozása jó szívvel ajánlható az elmúlt évtizedek oktatáspolitikai történéseinek háttere iránt érdeklődő kutatóknak, hallgatóknak, pedagógusoknak ugyanúgy, mint a tanítóképzés ügye iránt elkötelezett kollégáknak, vagy a Tanácsköztársaság, illetve az azt követő évtizedek feltárása iránt fogékony történészeknek.

Donáth Péter (2012, szerk.): Sorsfordító mozzanatok a magyarországi kisgyermekkori nevelőképzés, a Budapesti Tanítóképző Főiskola, az ELTE TÓK és épülete történetéből. Trezor Kiadó, Budapest, 256 oldal 